\title{
Malgorzata Grzywińska-Rąpca*
}

Uniwersytet Warmińsko-Mazurski w Olsztynie

\section{CZYNNIKI SPOLECZNO-DEMOGRAFICZNE DETERMINUJĄCE POZIOM WYDATKÓW MLODYCH KONSUMENTÓW NA ZAKUPY ZA POŚREDNICTWEM INTERNETU}

\section{Streszczenie}

Rozpoznanie zachowań gospodarstwa domowego czy konsumenta może wyjaśniać wiele procesów zachodzących na rynku, w tym również internetowym. Na podstawie przedstawionych $\mathrm{w}$ niniejszym opracowaniu elementów zachowania konsumpcyjnego studentów można stwierdzić, że istotnymi czynnikami wpływającymi na poziom wydatków na zakupy internetowe są cechy społeczno-demograficzne. Zaobserwowano zróżnicowanie poziomu wydatków tej grupy konsumentów w odniesieniu do formy studiowania (studia stacjonarne i niestacjonarne) oraz miejsca zamieszkania.

Słowa kluczowe: wydatki na zakupy online, zachowania młodych konsumentów, preferencje konsumentów

*malgo@uwm.edu.pl, Uniwersytet Warmińsko-Mazurski w Olsztynie, Wydział Nauk Ekonomicznych. 


\section{Wprowadzenie}

Postępujący rozwój technologiczny na świecie, zwiększenie świadomości cyfrowej społeczeństw znajdują odzwierciedlenie nie tylko w gospodarkach rynkowych, ale również mają wpływ na zmiany zachowań rynkowych konsumentów. Dostęp do nowoczesnych technologii, możliwość pozyskiwania informacji za pośrednictwem Internetu skutkuje pojawieniem się na rynku nowego typu konsumentów - klienta sklepów internetowych. E-konsument dzięki rozwojowi nowoczesnych technologii informatycznych uzyskał narzędzie w postaci Internetu, dzięki któremu uzyskiwanie informacji o produktach i usługach jest dużo szybsze i łatwiejsze (Bartosik-Purgat, 2011, s. 96). Zachowania konsumentów w wirtualnej przestrzeni rynkowej okazały się więc dalekie od tradycyjnych wyobrażeń, które akcentują więź z marką, poczucie przynależności czy poszukiwanie pomocy w zaspokajaniu swoich potrzeb. Współcześni konsumenci to jednostki niezależne, zaangażowane, aktywnie poszukując informacji oraz otwarte na zmiany.

\section{Zachowania e-konsumenta}

W ostatnich latach zaobserwowano wzrost zainteresowania zakupami internetowymi. Rozwój technologii IT spowodował powstanie terminu „e-konsument" (Wawrzynek red., 2000, s. 18). W związku z tym należy zwrócić uwagę na zmiany w zachowaniach konsumentów na rynku. E-konsument charakteryzuje się odmiennymi preferencjami, kieruje się w swoich decyzjach zakupowych innymi czynnikami niż w przypadku sprzedaży tradycyjnej. Co za tym idzie, wpływa to na powstanie nowych modeli zachowań rynkowych współczesnego konsumenta (Dąbrowska i in., 2009, s. 47).

Zachowania e-konsumentów to zorganizowany i ukierunkowany ciąg reakcji e-konsumentów, zachodzących w świecie realnym lub/i w Internecie, wywołanych czynnikami wynikającymi z dążenia do zaspokojenia potrzeb. Na zachowania nabywcze e-konsumentów wpływa wiele czynników, które mogą być klasyfikowane i dzielone według licznych kryteriów. Podziału dokonuje się ze względu na charakter czynników, ich powiązania z konsumentem, stopień niezależności od innych czynników, stopień mierzalności, źródło pochodzenia oraz skalę oddziaływania (Brzozowska-Woś, 2010, s. 396-410). 
Konsumenci nowej ery są coraz bardziej krytyczni i wymagający, a swoje decyzje zakupowe podejmują w racjonalny i przemyślany sposób. Ponieważ mają wyraźnie określone wymagania i potrzeby, nie reagują na wszystkie bodźce marketingowe, a ich zachowania nabywcze są efektem analiz, przemyśleń i chłodnej kalkulacji. Ze względu na wysoką świadomość potrzeb konsumenci coraz częściej z własnej inicjatywy dostarczają informacji (Grzywińska-Rąpca, 2012, s. 398).

E-konsument jest określany jako osoba, która wykorzystuje Internet niekoniecznie we wszystkich fazach procesu zakupu. Korzysta z Internetu z zamiarem ułatwienia swojego procesu zakupu czy zaspokojenia potrzeb, niekoniecznie jednak zamówienia produktu. W węższym znaczeniu e-konsument jest utożsamiany z osobą fizyczną, która przejawia i zaspokaja swoje potrzeby konsumpcyjne za pomocą produktów kupionych w Internecie. Zamawia dobra i usługi w Internecie, stając się finalnym nabywcą produktów oferowanych w sieci w celu zaspokojenia nie tylko swoich potrzeb osobistych, ale także potrzeb całego gospodarstwa domowego. Takie rozumienie pojęcia „e-konsument” dopuszcza sytuację, w której wszystkie działania przed zakupem i po nim są dokonywane przez e-konsumenta w sposób tradycyjny (np. pozyskiwanie informacji, dokonanie płatności), pod warunkiem że produkt lub usługa jest nabywana mimo wszystko w Internecie (Jaciow, Wolny, 2011).

\section{Cel i metody badawcze}

Celem opracowania jest przeprowadzenie analizy poziomu wydatków ponoszonych na zakupy przez Internet przez studentów w roku 2014. Analiza została oparta na badaniach ankietowych, przeprowadzonych $\mathrm{w}$ grupie studentów studiów stacjonarnych i niestacjonarnych. Materiałem w niniejszym opracowaniu były dane pierwotne, zgromadzone na podstawie przeprowadzonych badań $\mathrm{z}$ wykorzystaniem kwestionariusza ankietowego. Badania te miały na celu uzyskanie odpowiedzi na pytanie, czy forma kształcenia (studia stacjonarne i niestacjonarne) oraz miejsce stałego zamieszkania mają wpływ na decyzje zakupowe studentów w zakresie poziomu wydatków na zakupy z wykorzystaniem Internetu. Zgromadzone w wyniku badania ankietowego dane opracowano statystycznie za pomocą analizy ANOVA, która pozwala na analizę średnich w danej populacji 
- w tym przypadku uczestniczących w badaniu studentów studiów stacjonarnych i niestacjonarnych.

\section{Zróżnicowanie poziomu wydatków}

Przeprowadzone badanie metodą ankiety bezpośredniej obejmowało grupę studentów studiów stacjonarnych i niestacjonarnych. $\mathrm{Z}$ analizy danych wynika, że $66,67 \%$ wszystkich studentów robiło zakupy za pośrednictwem Internetu. Średnia miesięczna wartość dokonywanych zakupów ankietowanych zawierała się w przedziale do $100 \mathrm{zł} \mathrm{(rysunek} \mathrm{1).}$

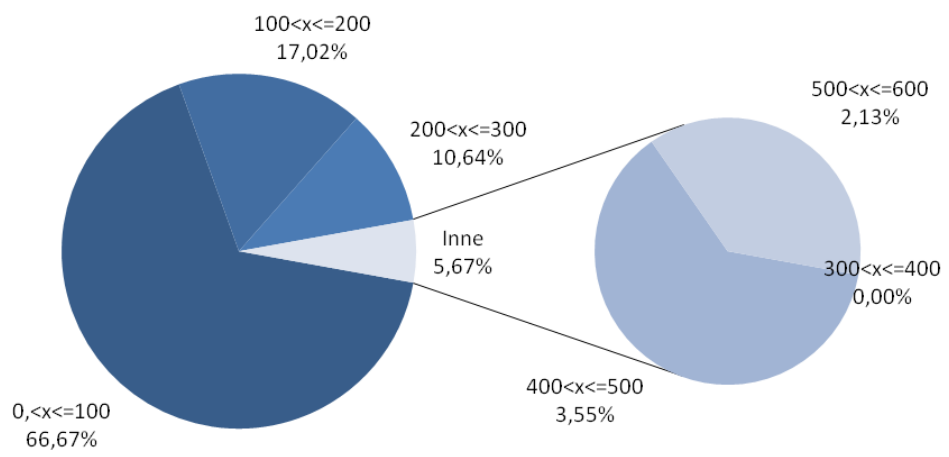

Rysunek 1. Poziom wydatków na zakupy internetowe

Źródło: opracowanie własne.

W wyniku przeprowadzonej analizy wariancji (ANOVA) uzyskanych danych dotyczących poziomu wydatków studentów studiów stacjonarnych i niestacjonarnych uzyskano średni wydatek studentów studiujących w systemie stacjonarnych na poziomie 136,36 zł. Wydatki na zakupy internetowe studentów stacjonarnych były o 16,17\% wyższe i stanowiły 158,42 zł (rysunek 2).

Można by oczekiwać, że ze względu na fakt uzyskiwanych dochodów przez studentów studiów niestacjonarnych (np. z tytułu zatrudnienia) średnie wydatki na zakupy internetowe powinny być znacząco wyższe. Należy jednak pamiętać, że ta grupa młodych osób ma wyższe wydatki miesięczne związane $\mathrm{z}$ wydatkami na podstawowe dobra konsumpcyjne (prowadzą samodzielne gospodarstwa domowe), ponoszą dodatkowe koszty związane z czesnym itp. W celu pogłębienia analizy danych w dalszej części pracy uwzględniono cechę demograficzną 
- płeć. Średni wydatek studentek na zakupy internetowe był niższy niż studiujących mężczyzn. Wśród studentów studiów stacjonarnych poziom wydatków na zakupy dokonywane $\mathrm{z}$ wykorzystaniem nowoczesnych technologii wynosił 142,38 zł (rysunek 3).

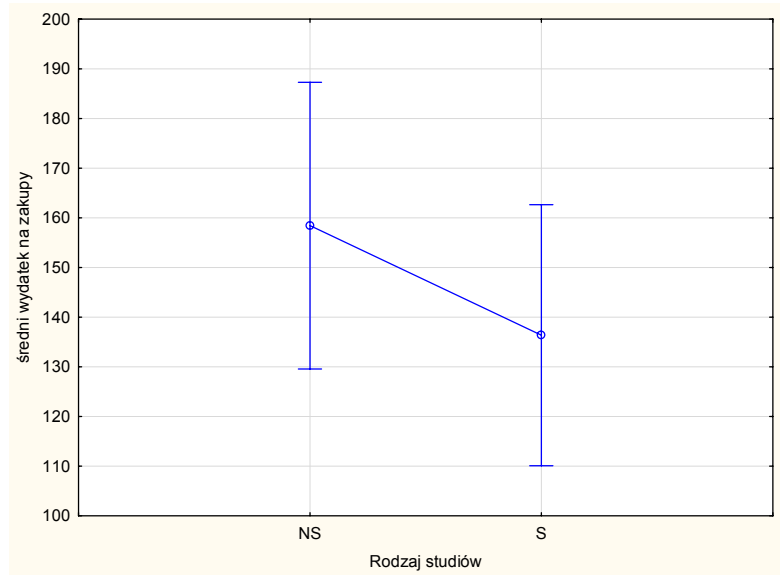

$\mathrm{NS}$ - studia niestacjonarne, $\mathrm{S}$ - studia stacjonarne.

Rysunek 2. Średnie wydatki na zakupy internetowe

Źródło: opracowanie własne.

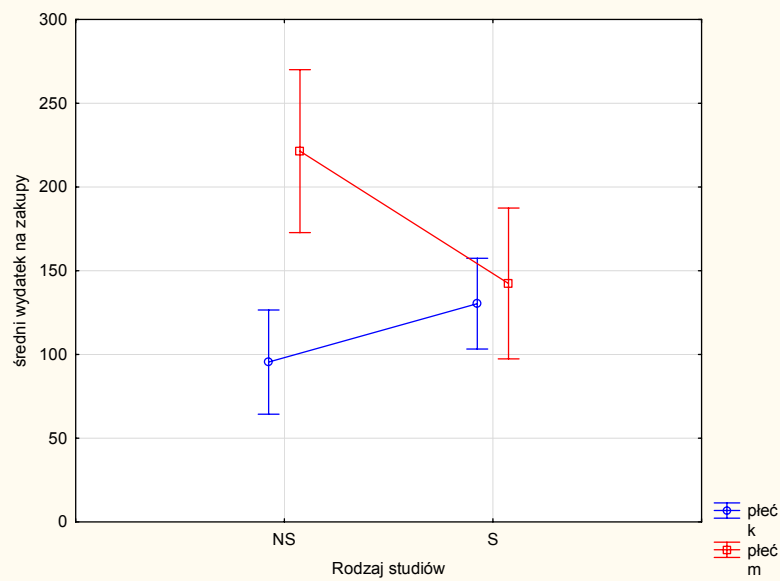

NS - studia niestacjonarne, $\mathrm{S}$ - studia stacjonarne.

Rysunek 3. Średnie wydatki na zakupy internetowe

Źródło: opracowanie własne. 
Średni wydatek na zakupy kobiet studiujących w systemie stacjonarnym kształtował się na poziomie 130,34 zł. Studentki studiujące stacjonarnie uczestniczące w badaniu przeznaczały na zakupy internetowe o $36,95 \%$ więcej aniżeli studiujące niestacjonarnie.

Dużą różnicę w średnim poziomie wydatków na zakupy internetowe można zaobserwować wśród mężczyzn. Studiujący niestacjonarnie przeznaczali średnio $221,38 \mathrm{zł}$, natomiast stacjonarni o $79 \mathrm{zł} \mathrm{mniej.}$

\section{Poziom wydatków, a miejsce zamieszkania}

Wykorzystanie nowoczesnych technologii, w tym Internetu, uwarunkowane jest umiejętnościami, ale również możliwości dostępu do technologii IT. Prowadzone działania związane z ujednoliceniem rynku cyfrowego w Polsce zmierzają do niwelacji różnic w wyposażeniu i dostępie do Internetu pomiędzy mieszkańcami miast i wsi. W przeprowadzonym badaniu średni wydatek na zakupy internetowe mieszkańców wsi był niższy niż zamieszkujących miasta (tabela 1).

Tabela 1

Średni wydatek na zakupy studentów studiów stacjonarnych

\begin{tabular}{|l|c|c|}
\hline \multirow{2}{*}{ Miejsce zamieszkania } & \multicolumn{2}{c|}{ płeć } \\
\cline { 2 - 3 } & kobieta & mężczyzna \\
\hline Wieś & 122,58 & 180,00 \\
\hline Miasto do 20 tys. mieszkańców & 164,28 & 94,28 \\
\hline Miasto 20-100 tys. mieszkańców & 120,00 & 140,00 \\
\hline Miasto 100-500 tys. mieszkańców & 142,50 & 170,00 \\
\hline Miasto powyżej 500 tys. mieszkańców & 60,00 & - \\
\hline
\end{tabular}

Źródło: opracowanie własne.

W przypadku studentów zamieszkujących miasta do 20 tys. mieszkańców średni wydatek kobiet był o 70 zł wyższy od wydatków na zakupy internetowe mężczyzn. W pozostałych grupach uwzględniających miejsce zamieszkania wydatki mężczyzn były wyższe (rysunek 4). 


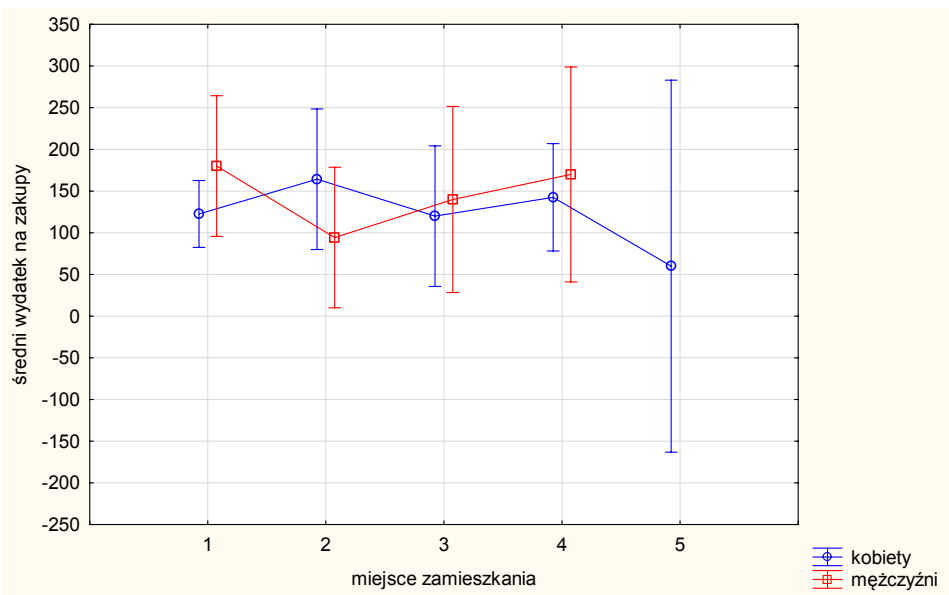

1 - wieś, 2 - miasto do 20 tys. mieszkańców, 3 - miasto 20-100 tys. mieszkańców, 4 - miasto 100-500 tys. mieszkańców, 5 - miasto powyżej 500 tys. mieszkańców.

Rysunek 4. Średnie wydatki na zakupy internetowe według miejsca zamieszkania Źródło: opracowanie własne.

O wiele wyższe różnice w średnich wydatkach na zakupy internetowe odnotowano w grupie studiujących niestacjonarnie (tabela 2).

Tabela 2

Średni wydatek na zakupy studentów studiów niestacjonarnych

\begin{tabular}{|l|c|c|}
\hline \multirow{2}{*}{\multicolumn{2}{|c|}{ Miejsce zamieszkania }} & \multicolumn{2}{c|}{ Płeć } \\
\cline { 2 - 3 } & kobieta & mężczyzna \\
\hline \hline Wieś & 91,81 & 300,00 \\
\hline Miasto do 20 tys. mieszkańców & 82,00 & 250,00 \\
\hline Miasto 20-100 tys. mieszkańców & 88,57 & 117,00 \\
\hline Miasto 100-500 tys. mieszkańców & 118,75 & 243,75 \\
\hline Miasto powyżej 500 tys. mieszkańców & 98,33 & \\
\hline
\end{tabular}

Źródło: opracowanie własne.

Niezależnie od miejsca zamieszkania respondentów studiujących niestacjonarnie średni poziom wydatków mężczyzn na zakupy dokonywane za pośrednictwem Internetu był wyższy. Wydatki kobiet w zależności od miejsca 
zamieszkania stanowiły od 30,6\% (wieś) do 75,7\% (miasto do 100 tys. mieszkańców) wydatków mężczyzn.

Średni poziom wydatków studentów studiujących niestacjonarnie zuwzględnieniem płci oraz miejsca zamieszkania zaprezentowano na rysunku 5.

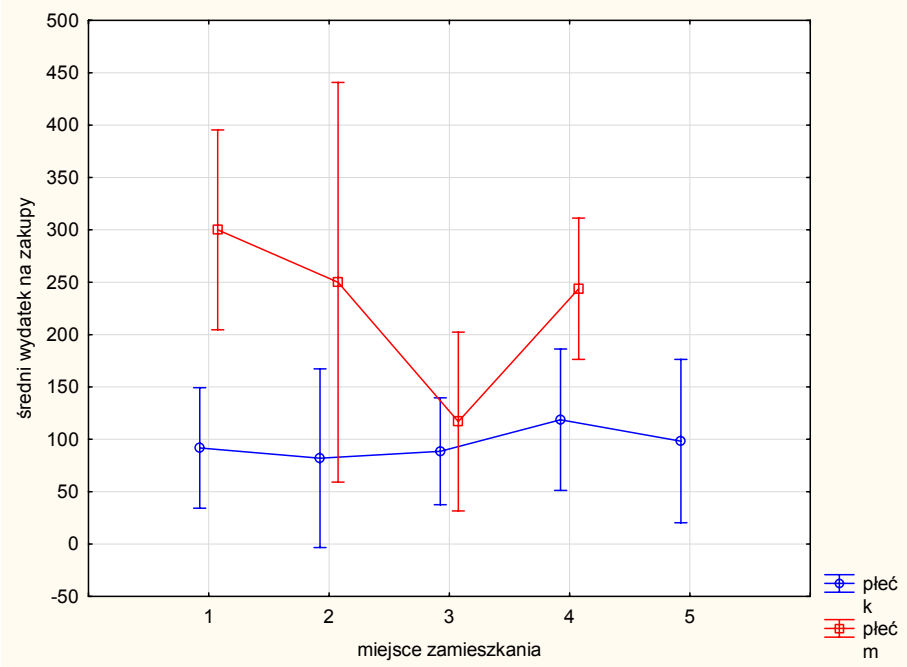

1 - wieś, 2 - miasto do 20 tys. mieszkańców, 3 - miasto 20-100 tys. mieszkańców, 4 - miasto 100-500 tys. mieszkańców, 5 - miasto powyżej 500 tys. mieszkańców.

Rysunek 5. Średnie wydatki na zakupy internetowe według miejsca zamieszkania Źródło: opracowanie własne.

\section{Podsumowanie}

Rozpatrując sferę konsumpcji, a w szczególności zachowania konsumpcyjne, można zauważyć, że działania różnych determinant powodują zmiany w poziomie konsumpcji. Zachowania konsumpcyjne wszystkich grup konsumentów zmieniają się w szybkim tempie. Podmioty gospodarcze reagują na potrzeby potencjalnych źródeł klientów, wykorzystując nowoczesne technologie w swoich działaniach. Konsumenci natomiast poszukują rozwiązań, które pozwolą utrzymać poziom konsumpcji danych towarów i usług przy mniejszych nakładach finansowych. Przeprowadzona analiza wykazała, że istnieje zróżnicowanie poziomu wydatków w zależności od takich czynników, jak płeć i miejsce zamieszkania respondenta. Poziom wydatków na zakupy internetowe kobiet był 
niższy tylko w przypadku osób deklarujących jako miejsce zamieszkania miasto do 20 tysięcy mieszkańców.

Analiza zachowań w zakresie zakupów internetowych respondentów uczestniczących w badaniu wskazuje na zainteresowanie tą formą handlu.

\title{
Bibliografia
}

Bartosik-Purgat M. (2011), Kulturowe uwarunkowania zachowań konsumentów na przykładzie młodych europejczyków, Wydawnictwo Uniwersytetu Ekonomicznego w Poznaniu, Poznań, s. 96.

Brzozowska-Woś M. (2010), Zachowania rynkowe młodych konsumentów w Internecie, $w$ świetle badań wybranej grupy studentów trójmiejskich uczelni publicznych, Zeszyty Naukowe nr 608, „Problemy Zarządzania, Finansów i Marketingu”, nr 15: Relacyjne aspekty zachowań konsumenckich, red. nauk. E. Rudawska, J. Perenc, Wydawnictwo Naukowe Uniwersytetu Szczecińskiego, Szczecin, s. 396-410.

Dąbrowska A., Janoś-Kresło M., Wódkowski A. (2009), E-ustugi a społeczeństwo informacyjne, Difin, Warszawa, s. 47.

Grzywińska-Rąpca M. (2012), Poziom wykorzystania technologii informatycznych w przedsiębiorstwach w Polsce, „Monografie i Opracowania SGH”, nr 589.

Jaciow M., Wolny R. (2011), Polski e-konsument. Typologia, zachowania, Onepress, Gliwice.

Wawrzynek J. red. (2000), E-commerce. Handel internetowy, Wydawnictwo Conlinuo, Wrocław, s. 18.

\section{SOCIO-DEMOGRAPHIC FACTORS DETERMINING LEVEL OF EXPENDITURE OF YOUNG CONSUMERS TO PURCHASE THROUGH THE INTERNET}

\begin{abstract}
Summary
Identifying consumer behavior may explain many of the processes taking place in the market, including the Internet. On the basis of these study consumer behavior elements students, important factors affecting the level of spending on Internet purchases
\end{abstract}


are socio-demographic characteristics. Observed differences in the level of expenditure of this group of consumers with regard to gender and place of residence.

Translated by Matgorzata Grzywińska-Rapca

Keywords: spending on online shopping, behaviour of young consumers, consumer preferences 